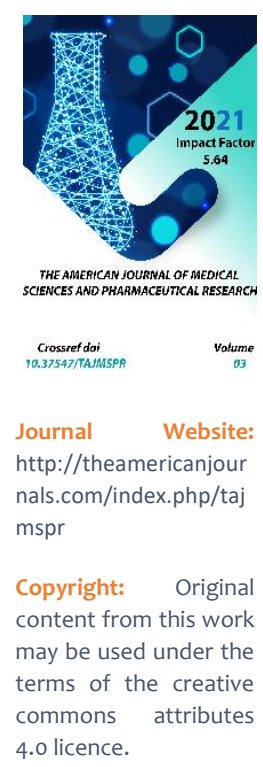

\title{
Factors Affecting The Health Of Organized Preschool Children
}

\author{
Zilolakhon Ulmasovna Adilova \\ Senior Teacher, School Of Public Health, Tashkent Medical Academy, Uzbekistan
}

Feruza Lutpillaevna Azizova

Doctor Of Medical Sciences, Associate Professor, Vice Rector For Research And Innovation, Tashkent Medical Academy, Uzbekistan

\section{ABSTRACT}

The article discusses the factors that effects to the health preschool children. The provided examples are taken on the circumstance of children activity in and out of school time in Uzbekistan.

\section{KEYWORDS}

Healthy lifestyles and disease prevention, life expectancy, pediatric morbidity, miscarriage, toxicosis, pregnancy,asphyxia,injuries, birth.

\section{INTRODUCTION}

At present, a number of measures have been taken to radically reform the education system in the country: the educational conditions of preschool education institutions have been updated; private preschools were established; Along with the revision of the education and upbringing system of preschool education institutions, one of the important tasks is to develop measures for early detection and prevention of various diseases among children in these institutions. In this regard, the Action Strategy for the five priority areas of development of the Republic of Uzbekistan for 2017-2021 emphasizes the importance of "... implementation of comprehensive measures to strengthen children's health, reduce disease and increase life expectancy through healthy lifestyles and disease prevention ..." [12]. In the set tasks, it is important to implement a set of measures aimed at strengthening and restoring the health of children in preschool education, the rehabilitation of children with frequent illnesses, early detection of disease risk factors. 
The aim of the study was to study the risk factors affecting the health status of preschool children and to develop prognostic tables that assess them.

\section{MATERIALS AND RESEARCH METHODS}

The object of the study is organized preschool children living in Tashkent, the subject of children's diseases, risk factors. The study was conducted in 4 districts of Tashkent and selected polyclinics from each district (15 polyclinics of Almazar district, 34 polyclinics of Chilanzar district, 10 polyclinics of Sergeli district, the central polyclinic of Yunus-Abad district). Indicators, rates and structure of pediatric diseases have been studied in the last 3 years based on the results of referrals and medical examinations to primary health care facilities.

\section{THE MAIN FINDINGS AND RESULTS}

Depending on the impact of medical and social factors on children's health, they are divided into 3 groups: 1. Biological factors (biological factors related to the parents in the perinatal period of the child, as well as during the first year of life); 2. Factors reflecting the lifestyle (social activity) of the child and the living conditions of the family (parents); 3. Factors characterizing the medical activity of the family and the organization of medical care for the family. Among the group of factors, those with the highest risk to children's health are identified and analyzed.

To comprehensively assess the health status of children and study the impact of lifestyle factors on it, we used one of the modern methods of evidence-based medicine, the "event control" research method. Incident group - 300 sick children (frequent patients children who became ill 3 or more times during the follow-up year or once, the period of illness lasted up to 25 days, as well as children with chronic diseases). The control group included 300 children who had never been ill during the observation period.

The results obtained. A differential study of the effects of factors such as lifestyle, living conditions, medical activity of parents on children at different ages showed that these factors affect the morbidity rates of children $[5,6,10,11]$. At the same time, it was found that the role (importance) of some factors and groups of factors varies depending on the age of the child.

The inter-genetic interval between biological factors is one of the factors strongly influencing children's health. It was noted that the incidence rates in children with the interval between births were inversely proportional to each other, and the smaller the interval, the higher the incidence. The risk of pediatric morbidity was found to be 2.20 times higher in children with a period between births of $1.5^{-2}$ years than in children aged 3 years or more (Table 1 ).

Many researchers (Mamatkulov B.M., Saidova L.B.) in their scientific work have studied the impact of consanguineous marriage on children's health. Our study found that children from families whose parents were related were 1.47 times more likely to be ill than children from families whose parents were not related.

The health status of young children is strongly influenced by the course of pregnancy, the weight of the baby at birth, and the health status at birth. Children born weighing less than 2,500 $\mathrm{g}$ and weighing more than 4,000 $\mathrm{g}$ were reported to have a higher risk of disease than children born with normal weight. When pregnancy was associated with complications 
(risk of miscarriage, toxicosis during pregnancy) or when the child was born with asphyxia, birth injuries, their risk was 2.21 times higher than in children born with normal pregnancies and uncomplicated births (SHN2.21).

The results of our studies have shown that the age of the mother during childbirth also has a significant impact on the health of children. In particular, it has been confirmed that children have a higher morbidity rate if the mother is younger than 19 and older than 40 years. Children of mothers under the age of 19 and over the age of 40 were reported to be 1.66 times higher than children of mothers between the ages of 19 and 40 .

The health of the parents determines the health of the family. Children in families where the parents had chronic illnesses or where one parent often had acute illnesses were found to have a 2.06-fold higher risk of getting sick than children born to healthy parents. It was also found that if a child falls into the group of patients frequently in the first 3 years of age, his or her risk of developing the disease in the age group of 3 years is 2.8 times higher.

Natural breastfeeding is critical in preventing disease and death in children. It was noted that the risk of disease in formula-fed children was 3.36 times higher than in natural-fed children. The duration of breastfeeding also affects the morbidity of children. Breastfed infants under 1 year of age were found to be 2.2 times less likely to become ill than breastfed infants under 3 months of age.

The influence of biological factors on child morbidity decreases sharply with the age of the child, as well as the role of factors such as lifestyle and medical activity increases.
Factors such as walking in the fresh air and its duration, adherence to sleep patterns, hardening procedures (regular bathing, massage, massage) were also identified in children of all age groups. It was noted that the risk of illness in children from families without treatment was 2.68 times higher than the risk of illness in children from families without treatment.

The risk of illness in children was found to decrease by 3.49 times even when they walked in the fresh air for at least 2 hours a day. These factors also increase as the child gets older.

The lifestyle and conditions of families also play an important role in shaping children's health. Among these group factors, maternal care is of particular importance. B.Mamatkulov (1982) divided maternal care into 3 groups in terms of quality to study the impact of maternal care on children's health. Group 1 - if the child is breastfed for 9-12 months, breastfeeding is followed, the child is not weaned in the summer, the duration of night sleep is 10-11 hours, daytime sleep is not less than 2 times on average; if the mother walks at least 3 hours a day in the fresh air, as well as every day in summer, 2-3 times a week in winter, exercise (massage), regular preventive examination by a doctor, maternity leave for at least 1 year continued, such maternal care was rated "good".

Group 2 - such breastfeeding, bathing, hardening (massage), prophylactic examination by a doctor, and the mother's maternity leave does not last until the age of 1 , if the child is breastfed, sleeps and walks regularly; Rated as "satisfactory".

The systematic violation of the above requirements has led to the assessment of maternal care as "unsatisfactory". 
When we study the indirect care of the mother for the health of the child by this criterion, the risk of disease in children in families with unsatisfactory maternal care in the first year of life is higher in families with good maternal care it was statistically determined that children were 4.11 times higher at risk of disease.

A correlation between childhood morbidity and living conditions has been reported in a number of similar studies [1, 2, 3, 4,9]. Family living (home) conditions have a direct impact on the health of family members and are of great importance in medicine and health care as a contributing factor in the occurrence of certain diseases. Therefore, every health worker, especially doctors engaged in preventive work, should be able to accurately assess the living conditions of the family and draw appropriate conclusions and develop measures to prevent disease.

The results of our study showed that the lower the quality description of the home environment, the higher the morbidity of children. The risk of illness in children with poor home conditions was reported to be 3.62 times higher than the risk of illness in children with good home conditions.

The fight against smoking is as important in children as it is in adults in the formation of a healthy lifestyle and prevention of disease. While parental smoking affects children's health from the time of pregnancy, babies become directly passive smokers after birth, and the impact of this harmful habit is even greater. In families with smokers in the first year of life, the risk of pediatric morbidity was found to be 3 times higher than in nonsmokers (SHN - 2.7).

One of the factors that negatively affect the health status of children is the mental state in the family or the interaction of family members. To assess the mental state, we divided all the families surveyed into 2 groups: Group 1 - families with a mental state in the family, the relationship is satisfactory, ie the family has parents, the relationship between them is good, family members do not have harmful habits.

If there is no parent in the family, or if there are frequent disagreements between them, if one of the family members is addicted to harmful habits, we classified such families as group 2, i.e. the relationship in the family is unsatisfactory bad mood. It was found that the risk of children becoming ill in families whose mental state was assessed as unsatisfactory was 3 times higher than in families whose mental state was unsatisfactory.

The medical activity of family members, especially the medical knowledge and skills of the mother, plays an important role in shaping the health of young children. If the medical knowledge of family members is sufficient, the doctor's recommendations in this family are fully, timely, prophylactic examinations are carried out systematically. In families with regular, systematic prophylactic examinations, the risk of disease in children was found to be 2.28 times lower than in children from families without regular, systematic prophylactic examinations (Table 3).

One of the most important tasks in the health of children of all ages is the ability of parents to identify the first signs of the disease, to see a doctor in a timely manner, their regular visits, complete treatment, knowledge of parents on disease prevention, first aid and the patient is able to arrange proper care for the child. 
According to our research, the risk of getting sick in different age groups increases by 2.5-3 times in families with irregular parents, irregular visits and those who do not understand the implementation of medical and hygienic recommendations or do not feel responsible. .

Due to the lack of knowledge of parents in the field of disease prevention, families do not take active measures in this regard. As a result, the risk of disease increases in such families. It is clear from this that factors such as the quality of disease prevention and treatment, the ability of parents to provide first aid and care for a sick child are important in maintaining and strengthening the health of children. It was found that the risk of illness increases by 2.5-3.0 times in families where the parents are unable to provide first aid during the illness and provide the necessary care to their children. It should be noted that the factors of increasing medical care and medical activity of parents, especially regular preventive examinations, are crucial in maintaining and strengthening the health of the child until the age of 7 years.

\section{CONCLUSIONS}

Thus, in order to assess the state of health, it is necessary to take into account the factors affecting children's health and the child's physical development and adaptive capabilities in preparing children for school. The comprehensive assessment of health status should be based on 4-x key criteria. The health of preschool children is not assessed without in-depth knowledge of the characteristics, biological and psychophysiological, as well as social.

\section{REFERENCES}

1. Azizova F. L. (2016) Solution of the problem of creating favorable hygienic conditions for teaching and upbringing of children with disabilities. Abstract of thesis. Doctor of Medical Sciences. Tashkent. - p. 25. (Азизова Ф. Л. Решение проблемы создания благоприятных гигиенических условий обучения и воспитания детей с ограниченными возможностями // Автореф... А.м.н.- Ташкент, -2016 - 25с.).

2. Baranov A.A., Lapin Yu.E., Yakovleva T.V. (2011) Children's health protection in the system of state policy. Bulletin RAMS. No 6. - pp. 8-12. (Баранов А.А., Лапин Ю.Е., Яковлева Т.В. Охрана здоровья детей в системе государственной политики // Вестн. РАMH. - 2011. - №6. - C. 8-12.).

3. Berman L.A. (2010) Formation of healthpreserving competencies of pupils and teachers // Culture/Science/Integration. No 9. - pp. 18-20. (Берман Л.А. Формирование здоровьесберегающих компетенций воспитанников и педагогов // Культура. Наука. Интеграция. - 2010. - №9. - С. 18-20.).

4. A.S. Golubev. (2005) Health status of preschool children and predictors of acute diseases: Dis. ... Candidate of Medical Sciences. - Moscow: - p. 120. (Голубев А.С. Состояние здоровья детей дошкольного возраста и предикторы острых заболеваний: Дис. ... канд. мед. наук. - М.: 2005. - 120 с.).

5. Druzhinin V.P., Florea V.I. (2009) Parameters of a healthy lifestyle of modern children and adolescents // Bulletin of the Moscow State University of Culture and Arts. No 4. - pp. 168-173 (Дружинин В.П., Флоря В.И. Параметры здорового образа жизни современных детей и подростков // Вестник Московского государственного 
университета культуры и искусств. 2009. -№ 4. C. 168-173).

6. Lisitsin Yu.P. (2010) Public health and healthcare. Textbook. - p. 202. (Лисицин Ю.П. Общественное здоровье и здравоохранение. // Учебник 2010 С. 202.).

7. Mamatkulov B., Avezova G.S. (2018) The concept of risk factors. Methods of calculating risk factors. Training manual. Tashkent: - p. 24. (Маматкулов Б, Авезова Г.С., Хавф омиллари хақида тушунча. Хавф омилларини хисоблаш усуллари. // Ўқув услубий қўлланма. Тошкент, -2018. -24 с.).

8. Mamatkulov B, Adilova Z.U., Mirzabaeva S.M. (2015) Practical application of scientific research. Textbook, Tashkent. Heir Publishing. - p. 81. (Маматкулов Б, Адилова 3.У., Мирзабаева С.М. Илмий такшириш ишларини амалиётда қўллаш // дарслик, Тошкент. Ворис нашириёти. - 2015. -81 c.).

9. Saidova L.B. (2010) Formation of the health of preschool children depending on the conditions of upbringing, Dis. Candidate of Medical Sciences. - Bukhara: - р. 130. (Саидова Л.Б., Формирование здоровья детей дошкольного возраста в зависимости от уловий воспитания, Дис. ... канд. мед. наук. - Бухара.: 2010. $-130 \mathrm{C}$ ).

10. E.A. Piven. (2010) The influence of a complex of social and hygienic factors on the health status of children in the first three years of life (based on materials from Moscow). Russian medical and biological bulletin named after Academician I.P. Pavlova. No 2. - pp. 6268. (Пивень Е.А. Влияние комплекса социально-гигиенических факторов на состояние здоровья детей первых трех лет жизни (по материалам г. Москвы) // Российский медико-биологический вестник им. академика И.П. Павлова. 2010. № 2. C. 62-68.).

11. WHO (2009). Global risk factors: Mortality and disease burden attributable to selected major risks. Geneva: World Health Organization. Available from: http://www.who.int/healthinfo/global_bu rden_disease/global_health_risks/en/. R. 13 (ВО3 (2009). Глобальные факторы риска: Смертность и бремя болезней, обусловленные отдельными основными рисками. Geneva: World Health Organization. Available from: http://www.who.int/healthinfo/global_bu rden_disease/global_health_risks/en/. p. 13).

12. Decree of the President of the Republic of Uzbekistan dated February 7, 2017 No PD-4947 "On the Strategy of further development of the Republic of Uzbekistan" (Ўзбекистон Республикаси Президентининг 2017 йил 7 февралдаги «Ўзбекистон Республикасини янада ривожлантириш Харакатлар стартегияси тўғрисида»ги ПФ-4947сонли Фармони). 